Article

\title{
Eastern Church Fathers on Being Human-Dichotomy in Essence and Wholeness in Deification
}

\author{
Olga Chistyakova
}

Citation: Chistyakova, Olga. 2021. Eastern Church Fathers on Being Human-Dichotomy in Essence and Wholeness in Deification. Religions 12 575. https://doi.org/10.3390/ rel12080575

Academic Editor: Jason Bruner

Received: 20 June 2021

Accepted: 21 July 2021

Published: 27 July 2021

Publisher's Note: MDPI stays neutral with regard to jurisdictional claims in published maps and institutional affiliations.

Copyright: (C) 2021 by the author. Licensee MDPI, Basel, Switzerland. This article is an open access article distributed under the terms and conditions of the Creative Commons Attribution (CC BY) license (https:// creativecommons.org/licenses/by/ $4.0 /)$.
Department of History of Philosophy, Faculty of Humanities and Social Sciences, Peoples' Friendship University of Russia (RUDN University), 117198 Moscow, Russia; chistyakova-ov@rudn.ru

\begin{abstract}
The article traces the formation of Eastern Christian anthropology as a new religious and philosophical tradition within the Early Byzantine culture. The notion "Patristics" is reasoned as a corpus of ideas of the Church Fathers, both Eastern and Western. The term "Eastern Patristics" means the works by Greek-Byzantine Church Fathers, who in the theological disputes with the Western Church Fathers elaborated the Christian creed. Based on an analysis of the texts of Greek-Byzantine Church Fathers, the most important provisions of Eastern Patristics are deduced and discussed, which determined the specificity of Christian anthropology. In this context, different approaches of the Eastern Fathers to the explanation of the Old Testament thesis on the creation of man in God's image and likeness and the justification of the duality of human essence are shown. Particular attention is paid to considering the idea of deification as overcoming the human dualism and the entire created universe, the doctrine of the Divine Logoi as God's energies, and the potential elimination of the antinomianism of the earthly and Divine worlds. The article reflects the anthropological ideas of the pre-Nicene Church Father Irenaeus, the non-canonical early Christian work The Shepherd of Hermas, and the teachings on the man of the classical Eastern Patristics period by Athanasius of Alexandria, Gregory of Nyssa, and Maximus the Confessor.
\end{abstract}

Keywords: Christian anthropology; Eastern Church Fathers; deification; energies and Logoi; man as the image and likeness of God; religious philosophy of Byzantium

\section{Introduction}

Eastern Christian Patristics in the period of its formation (4th-8th centuries) created a stable model of the theocentric universe, doctrinally and canonically justifying it, and stated the principles and fundamental ideas of Christian anthropology with a unique vision of an individual in their constant and uninterrupted relationship with God. This meant shaping a new religious-anthropological, and simultaneously, philosophical tradition within the framework of the emerging Byzantine culture. Indeed, the coming-to-life Christian anthropology included in its field of consideration the most important ideas related to the substantiation of human nature, ways of God-knowing and self-cognition, possibilities of preserving God's image as the meaning and goal of life, and achieving the lost likeness. Religious anthropology was also molded on the ground of analysis of human integrity and the correlation between the spiritual and bodily, freedom of choice and predestination, the relationship between the sacred and the mortal in an individual's life, the Divine and the earthly worlds.

I highlight the main fundamental problems discussed by the Eastern Fathers of the Church in developing the religious doctrine of man.

First of all, it should be emphasized that the Eastern Christian anthropological tradition was formed in the context of the exegesis of the Old Testament's position on the creation of man in the image of God. In developing and refining the dogma of the Incarnation of God (the Godman), the representatives of Eastern Patristics inevitably had to reveal the significance of image and likeness to reason the human in soteriological and 
eschatological contexts (Endean 2005, p. 226). The Greek Church Fathers argued for these concepts, showing the specificity of their manifestation in man as the crown of Divine creation and their necessity for individual salvation in the perspective of eternal life after death and the salvation of all humanity. In theoretical terms, however, despite some common understanding of these categories, each of the Eastern Fathers developed his particular conceptual vision and anthropological interpretation of the position-man as the image and likeness of God.

The next problem on which the Eastern Church Fathers directed their thoughts is explaining human life as an ascent along the path of deification to recover the lost godliness. The Byzantine theologians derived the concept of the individual, striving to achieve the absolute value and goal of all life- the spiritual state of Godlikeness. The perfect state of Godlikeness is attainable only in the challenging process of deification, when an individual improves themselves, perceiving the best qualities that unite them with the Creator and thereby comprehending the manifestations of God in the earthly world and self-cognizing.

At the same time, patristic thought has established the idea that an individual who has taken this path may not only achieve the coveted deification and approach a certain spiritual state and sense of unity with God (Climacus John 1908) but may also lose it forever. In this regard, the actions and thoughts of the individual were justified according to the opposing soteriological notions of death and salvation. Thus, human life appeared to be bifurcated, suggesting two main possible paths: Toward uplifting deification, perfect spirituality, and thus, salvation, or a worldly, temporal, sinful existence (Chistyakova 2019, p. 147). Gradually, a variety of theological arguments for the contradictory nature of man began to express a kind of reflexive conceptual unity of Eastern Christianity, bound by antinomianism as a kind of methodological principle.

Metodology. The present article investigates the abovementioned problems of Christian anthropology from a comparative perspective, scritinizing the concepts of early Christian theologians and the Church Fathers of the classical Nicene period. The article is methodologically built on the analysis of Christian primary sources- the original works of the Eastern Church Fathers. The hermeneutic method of studying early Christian and medieval texts is used, which allowed me to identify the main ideas of the representatives of Patristics and deduce the formation of Christian anthropology and the theocentric worldview in early Byzantium.

\section{Man as the Image and Likeness of God}

The reflection of the Old Testament thesis on the creation of man in God's image and likeness was discussed practically by all the Greek-Byzantine Fathers who participated in the Trinitarian (the 4th century) and especially in the Christological theological debates (the 5th-7th centuries) that took place on the territory of the Byzantine Empire (Whittow 1996).

However, prototypes of these ideas can already be found in the early Christian Fathers of the pre-Nicene period, such as Origen, Tertullian, Justin Martyr, and Irenaeus. St. Irenaeus (the 2nd century), in his polemic with the Gnostic teachings, clearly outlines the tendency of the philosophical and religious search for the essence of man, based primarily on the difference between the individual and the mortal world and his a priori belonging to God (which, in turn, gave hope for the possible achievement of the state of being likened to the Creator). The prospect of comparing man with God following the image and likeness grew out of these Irenaeus' reflections and later in a more profound theological formulation found application in the Patristics of the classical period ${ }^{1}$. Irenaeus, far from adhering to negative interpretations of the corporeal nature of man, defended the idea of a holistic understanding of the person. He taught of the equal and harmonious unity in man of the bodily and spiritual. The body, equally with the soul, is a gift of God, and therefore, the carnal-soul nature embodies the image of God in the individual, while the spiritual-soul essence relates to the likeness and marks the highest degree of individual morality (Irenaeus 1996). 
In the depths of his discourse on the image and likeness, Irenaeus lays the foundations of Christian thinking, where deification is the path of virtuous ascent to the Creator to achieve a likeness to the original image. Throughout life, beginning with overcoming his own created nature, through the rejection of the corruptibility of the world, humans aspire to the highest degree of perfection, equal to spiritual unity with God. Thus, Irenaeus writes- "man gradually succeeds and ascends to perfection, i.e., approaches the Uncreated, for the Uncreated is perfect, and such is God" (Irenaeus 1996, p. 435). Contemplation, or "seeing one's Master," is the attainment of the final stage of perfection, correlated with the possession of both the image and the likeness. In this way, the early Church Father anticipated the most crucial idea of Eastern patristic teaching concerning the spiritualization of man's inner world and his body, which further led to the anthropological phenomenon of the spiritualized person with its subsequent argumentation in medieval Byzantine philosophy.

In early Christian literature, which was not canonized, we also find compelling anthropological ideas with a somewhat naive vision of Christ's God-manhood and a prototype of the St. Father's concept of deification. The early Christian apocalyptic literary monument The Shepherd of Hermas, dating back to the 2nd century, is significant in this respect. Researcher I.S. Sventitskaya notes the moral implications of this highly revered work by the early Church: "Hermas develops a system of ethical requirements for Christians, who must follow the basic virtues personified in his visions by the virgins who escort the righteous inside the Church. Such virtues include faith, temperance, fortitude, patience, simplicity, cheerfulness, truthfulness, unanimity, love, etc." (Sventsitskaya 2014).

The ideals of early Christianity, expressed in symbolic and allegorical images in The Shepherd, would develop into more rationalized thoughtforms in the classical era of Eastern Patristics, interpreting deification as an elevating and perfecting path for man, drawing him from the earthly to the Divine. However, already in this book, the author had incorporated the ideas of personal attainment of deification as the highest state of spiritual unity with God, a superconscious and supersensible encounter with the Creator.

The Shepherd of Hermas contains moral concepts, precepts, norms, and commandments, expressed in a spirit of confrontation with sin and the emerging image of Satan as the embodiment of all that is evil and unrighteous in the world. Hence, Hermas paints man as quite contradictory and confused by the recognition of his sinfulness. A person strives for repentance. The Christian Church's setting is symbolically expressed in the construction of the stone Church by the righteous, those trying to take the sinless path, and those who have not yet repented but realized the need for repentance and faith. The symbolism culminates in Herma's description of the stacked stones, representing the Christian righteous, as well as the sinners who are just coming to realize the significance of the new religion. "'Those', she said, 'which go into the building without being polished, are those whom God has approved of, for they walked in the straight ways of the Lord and practiced His commandments.' 'But who are those who are in the act of being brought and placed in the building?' 'They are those who are young in faith and are faithful. But they are admonished by the angels to do good, for no iniquity has been found in them.' 'Who then are those whom they rejected and cast away?' 'These are they who have sinned, and wish to repent. On this account they have not been thrown far from the tower, because they will yet be useful in the building, if they repent. Those then who are to repent, if they do repent, will be strong in faith, if they now repent while the tower is building. For if the building be finished, there will not be more room for any one, but he will be rejected. This privilege, however, will belong only to him who has now been placed near the tower'" (Hermes of Philippopolis 2014). The unified Church's symbolic image pervades this work from the beginning to the concluding pages.

By the gross, I should note that the attitude towards the Old Testament thesis, originating already at the dawn of Christianity, led to the gradual affirmation in Eastern Patristics, and more generally-in Greco-Byzantine culture of the peculiar religious type of man, according to which the image of God is given to every person from his creation. The purpose of man is to preserve the image during his life, to follow it on the way of deification, 
thereby realizing in this world the higher plan of spiritual transfiguration and salvation ordained by the Creator. However, the Greek Church Fathers contain subtle conceptual differences in their theological understanding and interpretation of these notions of the Old Testament. The philosophical reflection on the Old Testament position contributed, in our opinion, to the fact that each of the Eastern Fathers created his original doctrine.

Athanasius of Alexandria, whose works belong to the classical stage of Patristics, has the doctrine of the comparability of man's Godlikeness to the good in its broadest sense. The seeds of this concept were already planted by Irenaeus, who noted that the aspiration toward the image and likeness in epistemological terms is the comprehension and discrimination between good and evil, without which the conscious and free adherence to religious canons and norms was impossible. St. Athanasius, however, gave these ideas fairly consistent and elaborate conceptual expression. As an adherent of the Alexandrian school of theology, for which the most important in explaining the meanings of Sacred Scripture was the application of the ancient philosophical heritage, Athanasius in his Against the Heathen treatise, establishes the correspondence among the concepts of similarity, good, and essence in theoretical reasoning about man and his being.

The human race, created in the image of God, was given both intelligence and the ability to comprehend its foundations for life. Through likeness to the Creator, man was given the ability to "know of this being" and the knowledge of God's eternity. Man from creation is not limited in comprehending the Creator and gaining the happiness of "conversing with God. As long as man is lifted in thought above natural and corporeal perceptions, trying to touch by the power of the mind the Divine, his mind is "collected in itself," and he can contemplate "the Father's image, the Word of God" (Athanasius of Alexandria 1994, p. 127). Since man is bound to God by the likeness, each individual can also see God in themselves. However, Athanasius reasoned that people have turned their minds away from that which is above them and have turned to that which is nearer to them, the body, and the senses. Seduction by self and sensual things led people to "self-love." By choosing "his own contemplation over the divinity" (Athanasius of Alexandria 1994, p. 128), artificial changes in his soul, destroying his original harmonious trinity of body, soul, and spirit. The originally spiritualized soul now exhibited the traits of mortal man-attachment to things and lusts, fear of separation from the body, fear of death. In other words, the soul became associated with what in Patristics was called the category of non-essential, i.e., not belonging to the world of the spiritual and Divine.

Athanasius then turns to the concept of good, explaining it through the human soul's free will. Created free, the soul can both turn toward the good (i.e., being) and away from it and gravitate toward evil (i.e., non-being). But the soul has an active nature, and therefore, its aspiration to being and non-being is infinite and unstoppable. "The being is good and the non-being is evil. And I call the being good, because it has for itself a model in the existent God; and I call the non-being evil, because the non-being is produced by the imaginations of men. The body has eyes to know the Creator. <...> But the soul, having escaped from contemplating that which is good and from turning its activity to it, in its delusion already turns it to the opposite" (Athanasius of Alexandria 1994, p. 130).

In his critique of Hellenistic philosophy and the heretics who ascribed "evil an autonomy," Athanasius came to the most important topic discussed in anthropological discourse, namely, the origin of evil and its confrontation with good. Since Athanasius related the good to the most critical category of likeness, he could not deviate in his solution of this question from the Church Fathers' tradition. The theologian denies the possibility of evil coming from God and is far from the idea of endowing evil with a self-sufficient existence. Athanasius continually appeals to the widely discussed notion of being (homoousion), arguing that evil was not and cannot be based initially on being. Evil is the opposite of being, since it is "not of God and not in God." Having turned away from being, i.e., from the divinity and good, people began to think of the carnal and sensual. They began to "fancy and imagine the non-essential" (Athanasius of Alexandria 1994, p. 133). Thus, the logic of Athanasius' reasoning leads to the idea of man's antinomian nature, which is eternally accompanied 
by a struggle between good and evil. For will chooses an individual path, and as it were, throws man into the inescapable contradiction of life.

As follows from the reasoning of Greco-Byzantine theologians, the thesis of the Old Testament a priori presupposed the need to justify the contradictory nature of man with a subsequent theological deepening of the problem. For the ideas of the image and likeness of God, they were inexorably linked to man's spirituality and the longing to regain his lost likeness on the path of self-improvement, provided for the other side, namely, the existence of a physical, passionate, God-avoiding nature. Not only did the dualism of human nature suggest an elevation to a transcendent and absolute being, but it also unified human beings with the perishable, corruptible world, in which humans are allowed to experience the same feelings and volitions that were characteristic of the Godman. Therefore, justifying and developing the Old Testament statement and elaborating the differences between the categories of image and likeness, the Greek-Byzantine Fathers at the same time found themselves in the field of philosophical and religious reflection on comprehending the antinomic essence of man.

\section{The Contradictory Human Nature}

The contradictory nature at the base of man's essence pervades Christian anthropology and is the main methodological principle that evokes the corresponding theoretical reasoning of the Church Fathers. Theologians commenced the search for the possibility of reconciling the two opposite natures-spiritual and sensual—in the integral unity of man. Gregory of Nyssa, a Cappadocian Church Father, made a tremendous contribution to developing the Christian doctrine of man. According to him, the duality of the human being is deliberately arranged by the Creator so that the high predestination of man is more clearly manifested. It is through the individual that the whole world becomes communicated to God: The Divine light is made visible, his glory is witnessed, "so the human nature also, as it was made to rule the rest, was, by its likeness to the King of all, made as it were a living image, partaking with the archetype both in rank and in the name" (Saint Gregory of Nyssa 2016, chapter IV).

In classical Patristics, however, the issue arose of juxtaposing the seemingly incompatible conceptions, i.e., the simultaneous coexistence in people of the spiritually exalted and the carnal, sinful. In drawing the notion of man's greatness related to the "image of the nature of the Creator," Gregory tries to resolve this dichotomy. He asks: "How is the incorporeal likened to the body? how is the temporal like the eternal? that which is mutable by change like to the immutable? $<\ldots>$ that which constantly dwells with evil, and grows up with it, to that which is absolutely free from evil? There is a great difference between that which is conceived in the archetype, and a thing which has been made in its image" (Saint Gregory of Nyssa 2016, chapter XVI).

In considering the far apart image (as created man) and God's origin in man (as uncreated Divine nature), the Cappadocian Father uses exegetical techniques and continues explaining the Old Testament position by interpreting the quote "male and female created he them" (Genesis 1:27). He stresses that the human duality is justified by being likened to the Divine origin, and second, by the distinction between male and female, which could not exist in the Godman. St. Gregory, therefore, sees the essence of man precisely in his contradictory nature: "While two natures-the Divine and incorporeal nature, and the irrational life of brutes-are separated from each other as extremes, human nature is the mean between them: for in the compound nature of man we may behold a part of each of the natures I have mentioned - of the Divine, the rational and intelligent element, which does not admit the distinction of male and female; of the irrational, our bodily form and structure, divided into male and female: for each of these elements is certainly to be found in all that partakes of human life" (Saint Gregory of Nyssa 2016, chapter XVI).

Specific to Gregory of Nyssa's reasoning is that he considers the order of human creation, emphasizing prioritizing the origin and existence in man of first the Divine (intelligent) nature, and then the human nature itself. He notes: "That the intellectual 
element, however, precedes the other, we learn as from one who gives in order an account of the making of man; < . . > For he says first that "God created man in the image of God" (showing by these words, as the Apostle says, that in such a being there is no male or female): then he adds the peculiar attributes of human nature, "male and female created He them" (Saint Gregory of Nyssa 2016, chapter XVI).

It should be noted that Gregory's notion of mind refers to the spiritual rather than the rational basis of man. In keeping with the emerging orthodox tradition of Eastern Christianity, the Byzantine theologian defended the view that man, through his spirituality (which includes the mind), comprehends God the Trinity, filling his soul with contemplation and awareness of the perfection and holiness of the infinite God. Scholars Eirini and Terezis clearly underline the depth of St. Gregory's thought: "The indwelling of the Trinity is within the human person. And of course with the term Trinity, it is meant the divine attributes of God and not His own being. As the godhead dwells within the soul, so is the soul able to relate to the person the knowledge of it $\langle\ldots\rangle$. The soul acts as a mirror, which projects into one's knowledge the very revelation of God. $<\ldots>$ This is the beginning of the knowledge of God with the heart-by the intimate presence of God Himself. Yet it is only faint, and is still blurred, as one would expect within a cloud. The soul must still be purified, and must become ever more accustomed to this new way of knowing" (Eirini and Terezis 2019, pp. 160-61).

The Russian philosopher V.M. Lourie emphasizes that in Gregory's works, the mind is not connected with any bodily organ yet correlates with spirituality caused by the heart. The mind for the Cappadocian Father meant "something much more sublime. The alternative to the brain as the 'seat' of the mind in the views of that era might have been the heart" (Lourie 1995, pp. 151-52). In this respect, ideologically, St. Gregory is at the origin of the so-called spiritual warfare of Hesychasm, where the basis of the ascetic life was the concept of the mind reduced to the heart through prayer. The Hesychasts developed methods of prayer that enabled them to immerse themselves in a state of unity with the Creator through the perception of the Divine Light. Hesychasm researcher Anita Strezova notes: "With the mind centered in the heart, the Hesychast repeated the words of the Jesus Prayer aloud, and then unceasingly in thought, until the prayer was no longer initiated by the person but became the vehicle of the Holy Spirit, affecting every conscious and unconscious response" (Strezova 2014, p. 55). The understanding of mind by Gregory of Nyssa and Gregory Palamas and his Hesychast followers meant the cultivation of spirituality, to which every kind of human activity, including rationality, is subordinated. It is possible to say that Gregory of Nyssa's anthropology, many centuries before the emergence of Hesychasm, anticipated forming the foundations of the Hesychast doctrine.

Let me return to the relationship between the all-unity and the individuality at the base of human nature. St. Gregory takes a rather philosophical approach to explain the reasons for the appearance of contradiction in the integral nature of man. The Christian phenomenon of the first man Adam did not presuppose antinomianism and duality. On the contrary, it was immanent to the existence of a particular universal nature that binds men into unity. God's creation of man originally had the character of universality, the oneness inherent in every individual, and it is this universal nature of humanity that can be restored per the original Divine image. Moreover, "The all-unity of human nature determines man's personal qualities and essentially distinguishes the individual from the personality. Hence, man's conformity to the Creator is not in any individual physical element, but in a common spiritual nature that unites the human and Divine worlds" (Chistyakova 2018, pp. 9-10). The unity of human nature sets the prospect of achieving a covenantal likeness to God, for it predetermines and makes possible man's perception of the heavenly qualities and the filling of his nature and his life with them.

However, according to Gregory, the first sin broke the unity of the spiritual and bodily and the initially consistent universality of personality; human nature is now supplemented by individuality. Henceforth man's essence is characterized by duality. Individuality, destroying the consistent nature of humanity, brings incompleteness and disharmony to 
the unity of human existence. Expressing only part of the whole world, it embraces the manifestations of sensuality and corporeality, carnal and sinful aspirations, departure from the righteous path to God. Therefore, it is the preservation of the universal spiritual nature associated with the original image of God given to man that is essential to man's salvation. According to Gregory, the Creator's image in man means a priori perfection, revealed in the absolute qualities inherent in the universal essence of the person, i.e., love, reason, kindness, wisdom, intelligence, beauty, striving for self-knowledge. All these higher constituents of the individual are antithetical to his individuality. To restore one's semblance, the individual must follow his universal nature all his life, which, in effect, meant a righteous ascent along the path of spiritualization of soul and body.

The same transformative qualities that unite each person to God were prescribed by many of the Eastern Fathers, following Gregory of Nyssa, in their struggle for an equal understanding of the two perfect natures of the Godman in Christological disputes ${ }^{2}$. Because of the universality of the human race, originating in God's breath (Gregory of Nazianzus), Patristics charted the path of the individual to spiritual unity with God. St. Gregory noted that each person's soul is "connected to the heavenly spirit" (Gregory of Nazianzus 1994, p. 43), is relentlessly supported by it, and therefore, it is initially prepared for the establishment of Godlikeness in the created world. The development of these ideas by the Greek-Byzantine Fathers made it possible to justify the salvation and eschatological immortality of the soul, attainable through the self-perfectionist path of deification.

\section{Deification and Achieving Human Wholeness}

The idea of deification has a special place in patristic thought. It constitutes the plot and conceptual basis of all discussions of man in the context of religious gnosis and the emerging Christian anthropological tradition. In particular, the Byzantine theologian Maximus the Confessor greatly contributed to the formation of the orthodox dogmas of Christianity and enriched the comprehension of human nature developed by the preceding Eastern Church Fathers. St. Maximus linked the essence of man and his being with a mystical vision of religious life and the attainment of individual unity with God in the process of deification. In his theological discourse, deification is a way of life for every Christian to know God as far as possible and overcome the contradiction between the earthly and Divine worlds to attain the covenant salvation. Researcher John McGuckin, assessing the theoretical merits of Maximus, notes: "In Maximus, high theology becomes merged with the deepest principles of spirituality and with the search for active motives for the moral and ascetic life. $<\ldots>$ The incarnation, seen as the high point of all human history, is the dynamic method and means of the deification of the human race; a spiritual re-creation of human nature that allows individuals the freedom needed to practice virtue, since all humans were formerly enslaved by passions" (McGuckin 2005, p. 97).

St. Maximus justified the most crucial Christian concept of deification as the potential ability and desire of man to perceive and assimilate God's energies, or Logoi, and strive for union with the Creator in the constant spiritual warfare of nature. According to the Saint, the source of deification is the image of God in the human being, inherent in creation. For this reason, the moral path of deification brings man into a relationship with the Creator, for "no one can serve God purely except by perfect purification of the soul" (Maximus the Confessor 1993a, p. 273).

Deification leads an individual up the Ladder of Divine Ascent, "from the earthly to the holy of the holies" (Climacus John 1908, chapter III), to that spiritual state which would be signified by the name God by grace. Man is given to become a "creaturely God by grace," whereas only the Godman Jesus was God "by essence." Following John Climacus, similar ideas were philosophically developed by Maximus: "God created us that we might be made partakers of the divine nature (2 Peter 1:4), and partakers of His essence, and be made like Him (1 John 3:2) according to gracious deification, for the sake of which all that is created and remains, and that not yet created is brought into being and is begotten" (Maximus the Confessor 1993a, p. 271). 
In substantiating the concept of deification in all the Eastern Church Fathers, the most important meaning was the dogma of the Incarnation of God. Through deification, man can overcome the contradiction between the Divine and mundane worlds due to the GodIncarnate in whom, according to theologian Georges Florovsky, "the highest and utmost measure of this assimilation is fulfilled" (Florovsky 1995, p. 214). Moreover, the purposes of an individual and the God-incarnate Jesus Christ are mutually complementary and unified, despite the initial contradiction of their two enclosed natures (Divine and human). Maximus actively defended the dyophysitism doctrine in connection with the justification of the idea of deification: "The solid and sure foundation for the hope of deification for human nature is the humanization of God, which makes man a god in the same measure in which God Himself became man. For it is clear that he who is made man without sin can also deify nature without putting it into divinity, insofar as he elevated it to himself, insofar as he humbled himself for man's sake" (Maximus the Confessor 1993a, p. 276). In this way, the duality of deification was indicated-it is accomplished both by the Divine will and by man throughout the righteous life.

Deification in Patristics, in its way, symbolizes the a priori coherence, the harmonious relatedness between man and the Divine, the sacred and mundane worlds. The philosophical depth of this meaning excluded notions of an impassable chasm between two seemingly opposing worlds. The Russian philosopher Vladimir Lossky noted that Eastern Patristics (e.g., Gregory of Nyssa) starts with what revelation tells us of God to discover what it is in man which corresponds to the divine image. This is a theological method applied to the knowledge of man, to anthropology" (Lossky 1957, n.p.).

However, just as the Godman dogma affirmed the two simultaneous indivisible and inseparable natures in Christ, so deification did not mean complete fusion with God or loss of his individual nature and dissolution in the spiritual-divine life. "The deification of man is not his absorption or dissolution. On the contrary, it is in this Godlikeness that the human truly becomes himself. For man is created in the image of God and is called to Godlikeness. $<\ldots .>$ Deification means inseparable connection, perfect harmony, and unity. Above all, inseparability (always "in communion with one another")" (Florovsky 1995, p. 214).

According to patristic thought (e.g., Maximus the Confessor, Gregory of Nyssa, Basil of Caesarea), the whole human race is involved in the Divine life, which is also manifested and implemented through humanity and within it. The human spirit does not innately belong to the Divine essence but mediates and acts as an active link in the unity of absolute Divinity and earthly sensuality. That is why so clearly the Church Fathers wrote out the idea of animated flesh and cultivated spirit and spirituality. It appeared that true life was a spiritualizing "dying" to an earthly world in which the fullness of Godlikeness could not be attained.

Deification is of the help in the pursuit of Godlikeness. I may describe the former as a Christian teaching and a special discourse in which every person sharing such ideals is involved. Deification concerning humanity is a unique way of being, outlining a perspective of existence connected with high religious morality ${ }^{3}$. The path to God is an incredibly difficult conscious overcoming of the world's materiality, purification from sensual dependencies and fleshly attachments (Maximus the Confessor calls this settling of the soul), and an endless ascent of mind and soul to the contemplation of God and union with Him. The Eastern Fathers charted this path as a ceaseless inner self-contemplation, self-discovery, inseparable from the idea of ascesis and ascetic practice (Kirabaev and Chistyakova 2020, p. 8 of 16).

The human activity in transforming themselves and the created world on the way of deification is symbolically described by Maximus in his work Mystagogy. Deification is the central goal of man, and everything created by God contributes to the unification of the earthly world with the Logos so that God is present in the whole human race. In this conciliar nature, St. Maximus saw the destiny of the free and intelligent deification of all beings. Above all, however, the individual must accomplish deification in himself, for he is a certain microcosmic image of the universe. "Let [man—author O.C.] as much as possible 
cherish the immortal and divine soul, which will be deified through the virtues, and let the flesh be despised as subject to decay and death and which may defile the dignity of the soul, if we do not care for it" (Maximus the Confessor 1993b, p. 168). Through his thinking and intelligent soul and righteousness, man unites earth and heaven, then spiritualizes his body to such an extent that he opens the way to the "intelligible" and the angelic world to unite himself with the Creator on the summit of love for God. For Maximus (as for many of the Eastern Church Fathers), it was characteristic to describe the culminating moment of the encounter with God, or the achieved deification, in the mystical state of love.

As a follower of the spiritual allegorical Catechetical School of Alexandria, St. Maximus expands and deepens his vision of man's main goal, expressing it symbolically in the simultaneous belonging of man to the world of the absolute and the world of the mortal, capable, however, of bringing them into a kind of universality. Lars Thunberg underlined Maximus' role in the forming of theological anthropology. According to Thunberg, St. Maximus considers the human being both a microcosm, including and reflecting the Universe, and a mediator who can generate all God's creatures and the Divine world in one wholeness (Thunberg 1995). If man fulfills the higher goal ordained, he achieves a perfect spiritual state and enters personal unity with God, and brings all the parts of the universe, the earthly and Divine worlds, into harmonious conformity. In this case, the universe will be an all-inclusive organism, where God, man, and the created universe coexist together and inseparably. Maximus speaks of such an existence as follows: "And there is one world composed of them both [mental and sensual-author O.C.], as one man composed of soul and body. According to the law [of the Creator] who has united them, each of these worlds, fused in unity, neither rejects nor denies the other, according to the law [of the Creator] who has united them. And according to this law, the logos of a unifying power is inherent in them, not allowing ignorance, notwithstanding the natural otherness [of the two worlds], of their hypostatic identity in [this] unity" (Maximus the Confessor 1993b, pp. 167-68). Thus, the justification of deification in the works of St. Maximus meant deriving the idea of the unity and harmony of the earthly and Divine worlds, the elimination of the contradiction of the spiritual and sensual in each person, and in the whole universe.

\section{Conclusions}

The article analyzes the ideas of the Eastern Church Fathers and traces the formation of the religious and anthropological tradition of Christianity in early Greek-Byzantine culture. The Byzantine theologians, along with developing dogmatics in the centuries-old Trinitarian and Christological debates, substantiated the doctrine of man, closely linking their life, thoughts, and aspirations to God. The Christological dogma of the Godman played the primary role in the formation of religious anthropology. The Eastern Fathers compared all their discussions of man to the incarnation of Christ, which helped them define the meaning and purpose of the individual in the earthly world. In outlining Christian anthropology, the Greek Fathers ideologically sought to elevate man above all created nature and to show the advantages of a spiritualized whole person. At the same time, theologians also attempted to expose man's imperfection, his burden by original and potential sin, and reveal his weaknesses and sensual vices. Therefore, in Greek-Byzantine anthropology, man began to be seen at the intersection of the relationship between God and the Universe, unfolding in the temporal continuum of human history.

In general, the anthropological doctrine of Eastern Christianity was formed based on patristic theorizing about the understanding of the Old Testament thesis on the creation of man in God's image and likeness. The subtle conceptual differences in their theological, and at the same time, philosophical discourse on man derived from various explanations of this fundamental position. For example, Athanasius of Alexandria associated image and likeness with good (being) and evil (non-being) concepts that equally possessed man. The confrontation between these poles determines, in Athanasius' thought, the way of human life. Gregory of Nyssa, a Cappadocian Father, linked likeness to a greater extent to the inherent universality of human nature (perfection, absoluteness) to which, after the original 
sin, the individuality, the sensuous singularity of each individual was added. Nevertheless, due to Creator's image preserved in the soul, human nature can regain its likeness and once again possess a spiritual oneness and the universality of nature.

At the same time, Byzantine theologians stressed that every Christian has a constant and irresistible urge to return to Godlikeness. The possibility of attaining that state was explained by the image of God, which belonged to man from his creation. Such consideration directed everyone to self-improvement and self-knowledge to ascend to a special spiritual state, a sense of unity with God. The Patristic justifications for this unity of man and God carried a paramount sense of the possibility of overcoming the antagonistic contradiction between the human and Divine worlds. Thus, the Christian notions of image and likeness brought into harmony the two phenomena of God and man. The Old Testament thesis was eventually realized in Greek Patristics as a kind of elimination of the dualistic human nature and the entire created universe based on the spiritual integrity of the human and Divine worlds.

In the theoretical embodiment of the problem of the relation between the image and the likeness, the Church Fathers inevitably came to justify the antinomic nature of man. The aspiration to achieve Godlikeness was deduced in the texts of the Fathers as the way of life of the individual, who is destined to bear the burden of the contradictory nature of his essence. Hence, the dual assessment of the nature of man in the writings of the Church Fathers. However, theologians stressed that the dualism of human nature is overcome by spirituality and reason for deification, i.e., the individual ascent to the absolute Divine world.

The phenomenon of man in Eastern Patristics was deduced not only in cosmological terms but also in symbolic and semantic, signifying the mediation between the absolute and the created worlds and marking the uniqueness of the created person, whose purpose is the sacred deification of the earthly world and spiritualizing its approach to God. Through the perfection of his essence, man can overcome the initial contradiction of his nature and unite the earthly and Divine worlds in a harmonious unity (for instance, through the perception of the Divine Logoi in Maximus the Confessor). Thus, the idea of deification in Eastern Christianity has a profound conceptual meaning, taking shape as an independent doctrine in the bosom of Christianity, inseparable from both theology and Christian anthropology.

Funding: This paper has been supported by the RUDN University Strategic Academic Leadership Program.

Institutional Review Board Statement: Not applicable.

Informed Consent Statement: Not applicable.

Data Availability Statement: Not applicable.

Conflicts of Interest: The author declares no conflict of interest.

\section{Notes}

1 I take St. Irenaeus under consideration, assigning him to the corpus of the predecessors for both the Eastern Church Fathers (or Eastern Patristics) and the Western Church Fathers (or Western Patristics).

2 For more details on the issue on Christology and doctrine of Godman please refer to: (Kelly 1988).

3 For details on the patristic understanding of deification as the essence of the human being please refer to: Nellas (1987), Khaled (2020); and on history of deification from the Bible origins with focusing on the patristic approaches, please refer to: Russell (2004). For perspective fundamental work, please see: Gavrilyuk (2021).

\section{References}

Athanasius of Alexandria. 1994. Against the Heathen. In CreationsWorks in 4 Vols. Moscow: Spaso-Preobrazhenskij Valaamskij monastyr', vol. 1, pp. 125-91.

Chistyakova, Olga V. 2018. The Issue of Free Will and Divine Predestination in the Western and Eastern Patristics in the Context of Orthodox (Soteriological) and Philosophical Differences. Logos et Praxis 17: 6-15. [CrossRef] 
Chistyakova, Olga V. 2019. Religious Anthropology of Eastern (Greek-Byzantine) Patristics. European Journal of Science and Theology 15: 145-55.

Eirini, Artemi, and Chrisros Terezis. 2019. The Mystical Theology as a Path of Man for the Divine Knowledge in the Writings of Gregory of Nyssa, Dionysius Areopagite, and Maximus the Confessor. De Medio Aevo 13: 153-76.

Endean, Philip. 2005. Christian Spirituality and the Theology of the Human Person. In The Blackwell Companion to Christian Spirituality. Edited by Arthur Holder. Malden, Oxford and Carlton: Blackwell Publishing, pp. 223-38.

Florovsky, Georges V. 1995. Eastern Fathers of the Fifth to Eighth Century. Moscow: Palomnic.

Gavrilyuk, Paul. 2021. The Oxford Handbook of Deification. Proposal, Table of Contents, and Contributors. Oxford: The Oxford Handbook of Deification, Available online: https:/ / www.academia.edu/44457864/The_Oxford_Handbook_of_Deification_Proposal_table_ of_contents_and_contributors (accessed on 12 July 2021).

Gregory of Nazianzus. 1994. Poemata Arcana. Poem 4. On the Universe. In Works of Gregory of Nazianzus, in 2 Vols. Sergiyev Posad: Typography of Trinity Lavra of St. Sergius, vol. 1, pp. 24-27.

Hermes of Philippopolis. 2014. The Shepherd of Hermas: Book of Visions. Translated by Joseph Barber Lightfoot. Edinburgh: CrossReach Publications, Kindle edition. Available online: https:/ /www.amazon.com/Shepherd-Hermas-J-B-Lightfoot-ebook/dp/B00MD1 6F44/ref=sr_1_1?dchild=1\&keywords=shepherd+of+hermas \%3A+book+of+vision+lightfoot\&qid=1627030369\&sr=8-1 (accessed on 23 July 2021).

Irenaeus. 1996. Works. Moscow: Pravoslavnyi Palomnik.

John, Climacus. 1908. The Ladder of Divine Ascent. Sergiyev Posad: Typography of Trinity Lavra of St. Sergius.

Kelly, John Norman Davidson. 1988. Early Christian Doctrines. New York: Columbia University Press.

Khaled, Anatolios. 2020. Deification through the Cross: An Eastern Christian Theology of Salvation. Grand Rapid: William B. Eerdmans Publishing Company.

Kirabaev, Nur, and Olga Chistyakova. 2020. Knowing God in Eastern Christianity and Islamic Tradition: A Comparative Study. Religions 11: 675. [CrossRef]

Lossky, Vladimir N. 1957. The Mystical Theology of the Eastern Church. London: Clarke, Available online: https: / azbyka.ru/otechnik/ Vladimir_Losskij/the-mystical-theology-of-the-eastern-church/ (accessed on 18 May 2021).

Lourie, Vadim M. 1995. Afterword to the Book by Gregory of Nyssa On the Making of Man. St. Petersburg: Axioma, pp. 147-74.

Maximus the Confessor. 1993a. Speculative and Actionable Chapters. In Philokalia, in 12 Vols. Moscow: Russian Spiritual Center, vol. 6, pp. 247-307.

Maximus the Confessor. 1993b. Mystagogy. In Works of Maximus the Confessor in 2 Vols. Moscow: Martis, vol. 1, pp. $154-84$.

McGuckin, John A. 2005. Christian Spirituality in Byzantium and the East (600-1700). In The Blackwell Companion to Christian Spirituality. Edited by Arthur Holder. Malden, Oxford and Carlton: Blackwell Publishing, pp. 90-106.

Nellas, Panayiotis. 1987. Deification in Christ: Orthodox Perspectives on the Nature of the Human Person. Crestwood: St. Vladimir's Seminary Press.

Russell, Norman. 2004. The Doctrine of Deification in the Greek Patristic Tradition. Oxford: Oxford University Press.

Saint Gregory of Nyssa. 2016. On the Making of Man. London: Aeterna Press, Kindle edition. Available online: https:/ / read.amazon.com (accessed on 20 May 2021).

Strezova, Anita. 2014. Hesychasm and Art: The Appearance of New Iconographic Trends in Byzantine and Slavic Lands in the 14th and 15th Centuries. Canberra: ANU Press, pp. 36-60.

Sventsitskaya, Irina S. 2014. Introduction to The Shepherd of Hermas. Edinburgh: CrossReach Publications, Kindle edition. Available online: https:/ / www.amazon.com/Shepherd-Hermas-J-B-Lightfoot-ebook/dp/B00MD16F44/ref=sr_1_1?dchild=1\&keywords= shepherd+of+hermas\%3A+book+of+vision+lightfoot\&qid=1627030369\&sr=8-1 (accessed on 23 July 2021).

Thunberg, Lars. 1995. Microcosm and Mediator. The Theological Anthropology of Maximus the Confessor. Chicago and La Salle: Open Court. Whittow, Mark. 1996. The Making of Orthodox Byzantium, 600-1025. London: Macmillan. 